\title{
Meta-Analytic Modeling of the Decline in Performance of Fungicides for Managing Soybean Rust after a Decade of Use in Brazil
}

Felipe Dalla Lana and Pierce A. Paul, Department of Plant Pathology, Ohio State University, Ohio Agricultural Research and Development Center, Wooster 44691; Claudia V. Godoy, Embrapa Soja, Londrina, PR, 86001-970, Brazil; Carlos M. Utiamada, Tagro, Londrina, 86070460, PR, Brazil; Luís Henrique C. P. da Silva, Agro Carregal, Rio Verde, 75907-454, GO, Brazil; Fabiano V. Siqueri, Fundação Mato Grosso, Rondonópolis, 78750-000, MT, Brazil; Carlos A. Forcelini, Universidade de Passo Fundo, Passo Fundo, 99052-900, RS, Brazil; David de Souza Jaccoud-Filho, Universidade Estadual de Ponta Grossa, 84030-900, PR, Brazil; Dulândula S. Miguel-Wruck, Embrapa Agrossilvipastoril, Sinop, 70770-901, MT, Brazil; Edson P. Borges, Fundação Chapadão, Chapadão do Sul, 79560-000, MS, Brazil; Fernando C. Juliatti, Universidade Federal de Uberlândia, Uberlândia, 38400-902, MG, Brazil; Hercules D. Campos, Universidade de Rio Verde, Rio Verde, 75901-970, GO, Brazil; José Nunes, Jr., Centro Tecnológico para Pesquisas Agropecuárias, Goiânia, 74130-012, GO, Brazil; Luciana C. Carneiro, Universidade Federal de Goiás, Jataí, 75801-615, GO, Brazil; Marcelo G. Canteri, Universidade Estadual de Londrina, Londrina, 86057-970, PR, Brazil; Margarida F. Ito, Instituto Agronômico, Campinas, 3012-970, SP, Brazil; Maurício C. Meyer, Embrapa Soja, Londrina, Brazil; Mônica C. Martins, Círculo Verde Assessoria Agronômica e Pesquisa, Luís Eduardo Magalhães, 47850-000, BA, Brazil; Ricardo S. Balardin, Universidade Federal de Santa Maria, Santa Maria, 97111-970, RS, Brazil; Silvânia H. Furlan, Instituto Biológico, Campinas, 13012-970, SP, Brazil; Valtemir J. Carlin, Agrodinâmica, Tangará da Serra, 78300-000, MT, Brazil; and Emerson M. Del Ponte, ${ }^{\dagger}$ Departamento de Fitopatologia, Universidade Federal de Viçosa, Viçosa, 36570-000, MG, Brazil

\begin{abstract}
An apparent decline of fungicide performance for the control of soybean rust in Brazil has been reported but the rate at which it has occurred has not been formally quantified. Control efficacy and yield response to three fungicides applied as single active ingredients (a.i.) - azoxystrobin (AZOX), cyproconazole (CYPR), and tebuconazole (TEBU)—and four applied as mixtures-AZOX+CYPR, picoxystrobin + CYPR, pyraclostrobin + epoxiconazole, and trifloxystrobin + prothioconazole (TRIF+PROT) were summarized using network meta-analytic models fitted to mean severity and yield data from 250 trials (10-year period). The effect of year was tested on both variables in a meta-regression model. Overall control

efficacy ranged from 56 to $84 \%$; the three single-a.i. fungicides performed the poorest (56 to $62 \%$ ). Yield increase for single-a.i. fungicides was as low as $30 \%$ but ranged from 47 to $65 \%$ for the premixes. Significant declines in both variables were detected for all fungicides except TRIF+PROT. For TEBU, control efficacy (yield response) declined the most: $78 \%$ (18\%) to 54\% (8\%) from 2004-05 to 2013-14. The recent surge of resistant populations of Phakopsora pachyrhizi to both demethylation inhibitor and quinone outside inhibitor fungicides is likely the driving force behind a significant decline after 4 years of fungicide use.
\end{abstract}

Soybean rust (SBR), caused by the fungus Phakopsora pachyrhizi Syd. \& P. Syd., is one of the most damaging foliar diseases of soybean (Glycine $\max$ (L.) Merr.) (Hartman et al. 1999; Li et al. 2010). After first being reported in Paraguay and Brazil in 2001, SBR quickly became established in several other countries in South America (Ivancovich 2005; Rossi 2003; Yorinori et al. 2005) and reached the continental United States in late 2004 (Schneider et al. 2005). SBR reduces healthy leaf area, causes premature defoliation (Kumudini et al. 2008; Yang et al. 1991), and has the potential to reduce attainable yield by up to $78 \%$ during severe epidemics (Dalla Lana et al. 2015).

In Brazil, environmental conditions are often favorable for the development of SBR during the cropping season (Del Ponte and Esker 2008; Del Ponte et al. 2006; Li et al. 2010). In addition, there are no environmental constraints for year-round survival of $P$. pachyrhizi. Early-season inoculum (urediniospores) originates from local or regional volunteer soybean and other host plants, and is easily blown in from neighboring countries (Pivonia and Yang 2004; Yorinori et al. 2005). A soybean-free period has been mandatory in several states of Brazil to reduce early-season inoculum. Breeding programs have focused on development of early-maturing cultivars, not only as an escape mechanism but also to allow a second summer crop. In

\section{${ }^{\dagger}$ Corresponding author: E. M. Del Ponte; E-mail: delponte@ufv.br}

*The $\boldsymbol{e}$-Xtra logo stands for "electronic extra" and indicates that one supplementary file is published online.

Accepted for publication 24 October 2017.

(c) 2018 The American Phytopathological Society fact, the widespread adoption of early-maturing cultivars, early sowing, and the mandatory soybean-free period in many Brazilian states is likely contributing to improved management of the disease in Brazil (Godoy et al. 2016a).

The majority of commercial soybean cultivars in Brazil are susceptible to SBR; however, major SBR resistance $(R)$ genes have been incorporated into cultivars by breeding programs. However, the effectiveness of these $R$ genes is limited by virulent $P$. pachyrhizi isolates (Miles et al. 2006). As a result of a limited number of resistant cultivars, management of the disease has relied on the use of fungicides. Since 2001, demethylation inhibitor (DMI) fungicides have been used as a single active ingredient (a.i.) or in premixes with quinone outside inhibitors (QoI), which increased in use following the first reports of reduced $P$. pachyrhizi sensitivity to DMI (tebuconazole [TEBU]) in 2006-07 trials conducted in the Cerrado region (Godoy et al. 2016a). Since 2014, succinate dehydrogenase inhibitor (SDHI) fungicides have become an option for farmers, given their good performance in the uniform field trials (UFT). The heavy dependence on fungicides for SBR control has not come without a significant increase in production costs to farmers. The overall cost was estimated at \$19.7 billion between the 2004-05 and 2013-14 seasons, mainly in fungicides and operations (Godoy et al. 2016a).

Fungicides have been evaluated annually since the 2003-04 season in a network of UFT (Supplementary File S1). A quantitative review of the efficacy of 22 fungicides evaluated in the UFT during the first 4 years of testing (up to 2006-07) showed control efficacy (percent reduction in disease severity) and yield response (percent increase in yield), both relative to the nontreated check, ranging from 19 to $86 \%$ and 17 to 65\%, respectively (Scherm et al. 2009). In general, DMI fungicides performed better than QoI when used as solo a.i. Among the DMI evaluated, prothioconazole (PROT) and TEBU performed best, with mean control efficacy of 63 and $68 \%$, respectively, and mean 
yield response of 32 and 60\%, respectively. However, premixes of QoI and DMI, especially those containing cyproconazole (CYPR), performed significantly better than DMI or QoI alone (Scherm et al. 2009).

The application of DMI alone, especially more cost-effective formulations of TEBU but also mixtures of DMI and QoI, have been largely overused over the years. Fungicide resistance studies reported P. pachyrhizi populations with decreased sensitive to DMI and QoI a.i. (Klosowski et al. 2016; Schmitz et al. 2013). In fact, isolates of $P$. pachyrhizi collected during the 2010 growing season exhibited mutations and overexpression of the CYP51 gene (Schmitz et al. 2013), which are associated with reduced sensitivity to DMI a.i. (Hulvey et al. 2012; Ma and Tredway 2013; Stammler et al. 2009). In addition, $P$. pachyrhizi isolates possessing the F129L substitution associated with partial resistance to QoI were recently reported (Klosowski et al. 2016). Uniform fungicide trial data appeared to provide additional evidence for the selection for resistance or, at the very least, suggested a decline in sensitivity within the local $P$. pachyrhizi populations to multiple fungicides, because efficacy has been relatively low and apparently decreasing in recent years compared with previous reports (Godoy et al. 2016a). However, such decline has not been analyzed, especially with regards to yield response, combining all available evidence using a robust inferential statistical framework. Meta-analysis, a technique that combines results from primary studies following defined criteria, provides a way to test whether and quantify how much of the percent efficacy and yield response is reduced over time (Madden and Paul 2011; Madden et al. 2016). Therefore, we aimed to assess whether there was a significant decline in control efficacy and yield response to seven of the most widely used commercial fungicides (applied as either solo QoI or DMI or premixes of the two chemistries) evaluated in the UFT for a minimum of 4 years within a 10-year period (2004-05 to 2013-14). We further quantified the relative rate of decline for both responses using year as a moderator variable in network meta-regression models.

\section{Materials and Methods}

Dataset description. We used the data available from Brazilian UFT conducted during 10 consecutive growing seasons (between 2004-05 and 2013-14) to evaluate the effects of selected fungicides on SBR severity and yield. During this period, 250 trials were conducted, and 58 treatments, which consisted of different combinations and rates of a.i., were evaluated. SBR severity index (percentage of diseased and defoliated leaves) data were available for all trials, and only five trials did not report yield data. Trials were conducted across 12 states, making up the major soybean-growing regions in Brazil, with a wide range of environmental conditions. Annual summaries of fungicide efficacy results from these UFT have been previously reported.

In general, all trials followed the same experimental design and had a common set of treatments evaluated during each growing season. In all cases, a susceptible soybean cultivar was sown in six, $5 \mathrm{~m}$ length row plots, arranged in a randomized complete block design, with four replications. In most of the trials $(n=188)$, two fungicide sprays were applied at label-recommended rates; the first at the R1 (beginning flowering) growth stage, followed by a second at R5 (beginning seed set) (Fehr et al. 1971). Fungicides were sprayed with a $\mathrm{CO}_{2}$ backpack sprayer, calibrated for a volume of at least 120 liter ha ${ }^{-1}$. Mineral oils were used as adjuvants according to the manufacturer. For azoxystrobin (AZOX), the adjuvant Nimbus (Syngenta, São Paulo, Brazil) was used at a rate of $0.5 \%$ vol $\mathrm{vol}^{-1}$ in all seasons. AZOX+CYPR also used Nimbus at a rate of $0.5 \% \mathrm{vol} \mathrm{vol}^{-1}$ for all seasons, except during 2012-13 and 2013-14, when the rate of 0.6 liter ha ${ }^{-1}$ was used. Picoxystrobin (PICO) + CYPR included Nimbus at rates of $0.5 \% \mathrm{vol} \mathrm{vol}^{-1}$ (2007-08), 0.5 liter ha $\mathrm{ha}^{-1}$ (2008-09 and 2009-10), 0.45 liter ha ${ }^{-1}$ (2010-11), and 0.75 liter ha ${ }^{-1}$ (2011-12 to 2013-14). Pyraclostrobin (PYRA) + epoxiconazole (EPOX) included Assist (BASF, São Paulo, Brazil) at a rate of 0.5 liter $\mathrm{ha}^{-1}$ (between the 2008-09 and 2013-14 seasons) and no adjuvant used during the 2006-07 season. Trifloxystrobin (TRIF)+PROT included Aureo (Bayer, São Paulo, Brazil) at rates of 0.4 liter ha ${ }^{-1}$ (2008-09 and 2010-11) and 0.25 liter ha ${ }^{-1}$ (2011-12 to 2013-14). CYPR and TEBU included no adjuvant added to solution. Occasionally, additional applications were made in some trials. In particular, under extremely disease-conducive environmental conditions, up to two additional fungicide sprays were applied: three applications were made in 46 trials and four in 6 trials. One spray was made in only two trials and the number of applications was not reported for eight trials. All crop management and weed and insect control practices followed state or regional recommendations, except for planting date, which was deliberately delayed in order to increase the likelihood of SBR epidemics due to increased inoculum density later in the season.

Treatment selection criteria. Of all treatments tested in the 250 UFT (hereafter studies), only those evaluated during at least four growing seasons (consecutively or not), including 2013-14, and compared with at least a nontreated check treatment in the same trial, were selected for inclusion in the analyses. Seven fungicides, including one QoI, two DMI, and four premixes of DMI + QoI, met the criteria and were selected (Table 1). The number of individual trials in which these fungicides were tested ranged from 79 to 248. There were different trial designs (the same fungicides tested in a trial) and number of fungicides being compared directly in the same trial: 59 trials compared all seven fungicide treatments, 22 included six of the seven, 28 included five, 43 included four, 40 included three, 57 included two of the seven, and 1 included just one of the seven.

Disease severity index and soybean yield. SBR developed naturally in all trials. The final disease severity index was assessed at the

Table 1. Summary statistics for soybean rust severity and soybean yield for seven fungicide treatments and a nontreated check evaluated in a network metaanalysis of 250 uniform field trials conducted from 2004-05 to 2013-14 in Brazila

\begin{tabular}{|c|c|c|c|c|c|c|c|c|c|c|}
\hline \multicolumn{2}{|c|}{ Fungicide } & \multirow[b]{2}{*}{ Rate (a.i. ha ${ }^{-1}$ ) } & \multicolumn{4}{|c|}{ Severity (\%) } & \multicolumn{4}{|c|}{ Yield (kg.ha- $\left.{ }^{-1}\right)$} \\
\hline Code & Active ingredient & & $N$ & Median & Q1 & Q3 & $N$ & Median & Q1 & Q3 \\
\hline CHECK & Check & - & 250 & 59.3 & 37.8 & 77.1 & 245 & 1,898 & 1,357 & 2,410 \\
\hline AZOX & Azoxystrobin & 50 & 79 & 31.3 & 13.9 & 55.8 & 75 & 2,330 & 1,844 & 2,847 \\
\hline CYPR & Cyproconazole & 30 & 146 & 31.4 & 12.7 & 48.8 & 142 & 2,394 & 1,899 & 2,833 \\
\hline TEBU & Tebuconazole & 100 & 248 & 22.5 & 9.1 & 46.8 & 243 & 2,466 & 1,869 & 2,976 \\
\hline \multirow[t]{2}{*}{$\mathrm{AZOX}+\mathrm{CYPR}$} & Azoxystrobin + & 60 & 212 & 8.9 & 3.0 & 26.9 & 207 & 2,702 & 2,236 & 3,204 \\
\hline & Cyproconazole & 24 & $\ldots$ & $\ldots$ & $\ldots$ & $\ldots$ & $\ldots$ & $\ldots$ & $\ldots$ & $\ldots$ \\
\hline \multirow[t]{2}{*}{$\mathrm{PICO}+\mathrm{CYPR}$} & Picoxystrobin + & 60 & 144 & 10.5 & 3.3 & 24.6 & 140 & 2,645 & 2,307 & 3,212 \\
\hline & Cyproconazole & 24 & $\ldots$ & $\ldots$ & $\ldots$ & $\ldots$ & $\ldots$ & $\ldots$ & $\ldots$ & $\ldots$ \\
\hline \multirow[t]{2}{*}{ PYRA+EPOX } & Pyraclostrobin + & 66.5 & 154 & 14.4 & 5.6 & 30.0 & 150 & 2,696 & 2,211 & 3,221 \\
\hline & Epoxiconazole & 25 & $\ldots$ & $\ldots$ & $\ldots$ & $\ldots$ & & 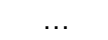 & $\ldots$ & $\ldots$ \\
\hline \multirow[t]{2}{*}{ TRIF+PROT } & Trifloxystrobin + & 60 & 109 & 8.4 & 2.8 & 22.5 & 105 & 2,969 & 2,508 & 3,460 \\
\hline & Prothioconazole & 70 & $\ldots$ & $\ldots$ & $\ldots$ & $\ldots$ & $\ldots$ & $\ldots$ & $\ldots$ & $\ldots$ \\
\hline
\end{tabular}

${ }^{\mathrm{a}} N=$ number of trials in which a given treatment was evaluated, $\mathrm{Q} 1=$ first or lower quartile of the data, and Q3 = third or upper quartile of the data. 
plot level at four arbitrarily selected points in each plot at the full-seed growth stage (R6). A minimum of 10 leaves was examined at each of three heights within the crop canopy, and percent leaf area exhibiting symptoms characteristic of SBR was assessed by experienced personnel with the aid of a standard area diagram (Godoy et al. 2006). In addition, premature defoliation due to SBR was recorded as $100 \%$ severity. Consequently, plot-level severity index as defined in this study took both severity on attached leaves and defoliation into consideration; this severity index was previously reported to correlate strongly with yield (Dalla Lana et al. 2015). The plots were harvested after full maturity (R8) and mechanically threshed, and seed weight and moisture content were obtained. Yield was adjusted to $13 \%$ moisture and calculated in kilograms per hectare.

Overall efficacy and yield response. In a preliminary data analysis step, least squares mean severity and yield for all treatments evaluated (including the nontreated check) and residual variances were estimated for each trial. To obtain these estimates, separate linear mixed models were fitted to the severity and yield data for each
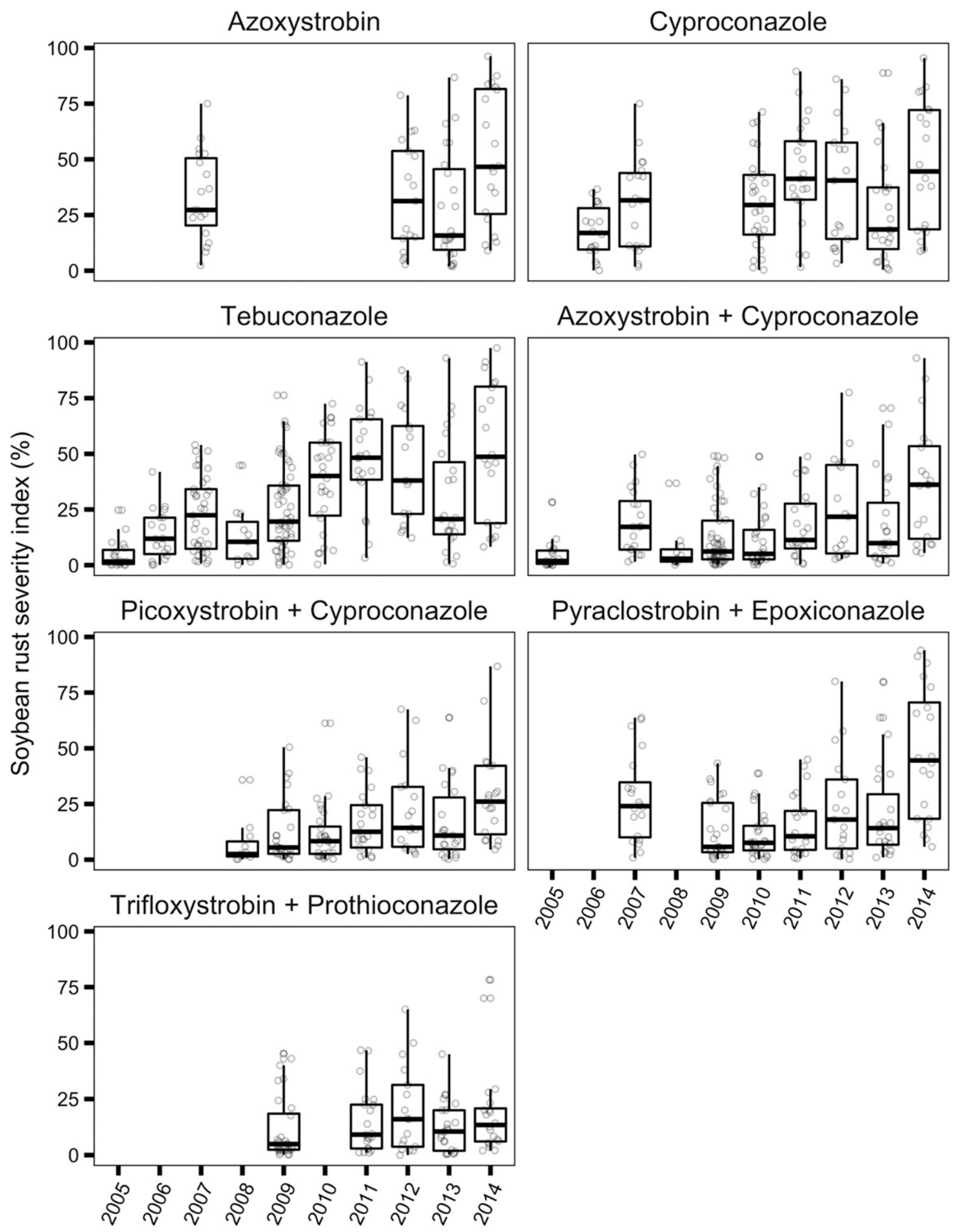

Fig. 1. Box plots showing the within-season distribution of mean soybean rust severity (\%) for different fungicide treatments across a range of uniform field trials conducted yearly from the 2004-05 to 2013-14 growing seasons in Brazil to evaluate the performance of fungicides on soybean rust and yield. Dots represent individual trial means, averaged across blocks. Upper and lower edges of each box show the 75 th and 25 th percentiles of the data, respectively, whereas the solid lines within each box show the media for each year across all trials and the vertical solid lines are the upper and lower whiskers (1.5 times the interquartile distance). 
trial using the MIXED procedure of SAS (Littell et al. 2006). In the model, treatment was defined as a fixed effect and block as a random effect. The lsmeans statement was used to estimate least squares means for both responses. A data matrix consisting of the estimates for each of the seven selected fungicides $\left(\hat{\mu}_{T}\right)$ and the nontreated check $\left(\hat{\mu}_{C}\right)$, together with the residual variances, was created and used for meta-analysis. These two datasets containing the mean estimates for each treatment and the residual variances for the trial, together with the other trial and treatment-related variables, are available at the Open Science Framework (https://osf.io/7d3ch/).

As described by Madden and Paul (2011) and Paul et al. (2008), a log-transformation was applied to the estimated means, and separate multitreatment (network) meta-analytic models were fitted to the data for each response (severity index or yield) using the MIXED procedure in SAS as described (Madden et al. 2016; Paul et al. 2008, 2010). The models can be written as:
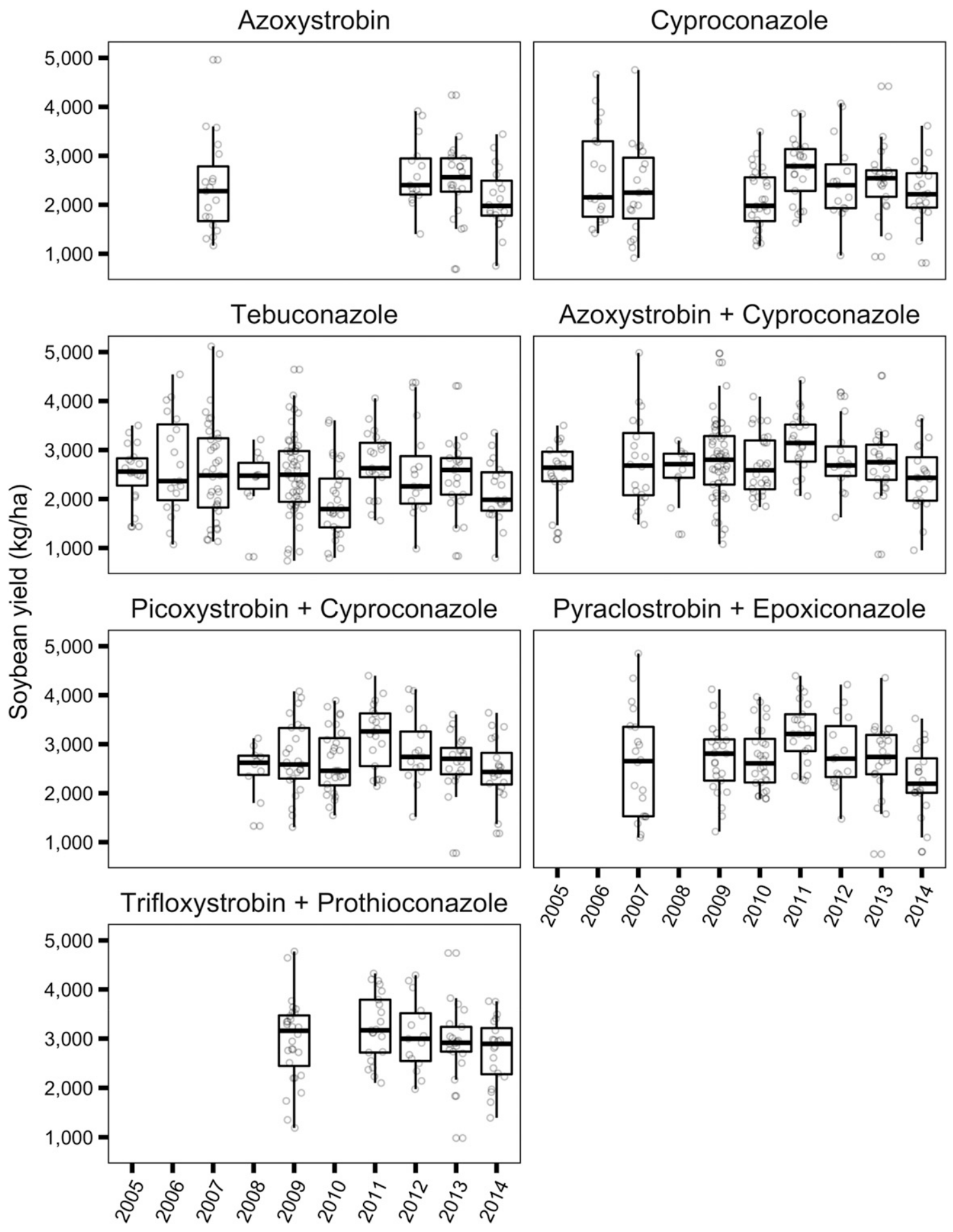

Fig. 2. Box plots showing the within-season distribution of mean soybean yield ( $\mathrm{kg} / \mathrm{ha}$ ) for different fungicide treatments across a range of uniform field trials conducted yearly from the 2004-05 to 2013-14 growing seasons in Brazil to evaluate the performance of fungicides on soybean rust and yield. Dots represent individual trial means, averaged across blocks. Upper and lower edges of each box show the 75th and 25th percentiles of the data, respectively, whereas the solid lines within each box show the media across all trials for each year and the vertical solid lines are the upper and lower whiskers (1.5 times the interquartile distance). 


$$
Y_{i} \sim N\left(\mu \sum+\mathrm{S}_{\mathrm{i}}\right)
$$

where $Y_{i}$ is the vector of $\log$ mean response (severity or yield) for the seven treatments plus the nontreated check for the $i$ th study, $\mu$ is a vector representing the mean $Y_{i}$ across all studies, $\Sigma$ is a, $8 \times 8$ between-study variance-covariance matrix, and $S_{i}$ is the withinstudy variance-covariance matrix for the $i$ th study. $N(\bullet)$ indicates a multivariate normal distribution. The elements of $S_{i}$ were incorporated into the model-fitting procedure as weights calculated as the inverse function of the within-study variance for each treatment from each study, as described (Paul et al. 2008).

Overall mean log response ratios (treatment/nontreated check) for severity and yield $\left(\bar{L}_{S e v}\right.$ and $\left.\bar{L}_{Y l d}\right)$, were estimated for each fungicide relative to the check. Because mean log response ratio $(\bar{L})$ is equal to the difference of logs, $\bar{L}$ was estimated as $\bar{L}=\hat{\mu}_{T}-\hat{\mu}_{C}$ using estimate statements in MIXED, where $\hat{\mu}_{T}$ and $\hat{\mu}_{C}$ are estimated mean log severity or yield for a treatment and the untreated check, respectively. The 95\% confidence intervals (CI) around predicted log response ratios were likewise estimated for each treatment relative to the check. To obtain overall mean percent SBR control $\left(\bar{C}_{S e v}\right)$, yield response $\left(\bar{Y}_{Y l d}\right)$, and their corresponding $95 \% \mathrm{CI}, \bar{L}_{S e v}$ and $\bar{L}_{Y l d}$ and the upper and lower limits of the $95 \% \mathrm{CI}$ around $\bar{L}_{s e v}$ and $\bar{L}_{y l d}$ were backtransformed as $\bar{C}_{S e v}=\left[1-\left(\exp \left(\bar{L}_{S e v}\right)\right] \times 100\right.$ and $\bar{Y}_{Y l d}=\left[\exp \left(\bar{L}_{Y l d}\right)-\right.$ $1] \times 100$, respectively (Paul et al. 2008).

Effect of year on control efficacy and yield response. To evaluate the temporal change in the control efficacy and yield response, we expanded the previous model (model 1) to include year as a continuous moderator variable. The expanded model can be written as:

$$
Y_{i} \sim N\left(\mu+\delta_{i}, \sum+\mathrm{S}_{\mathrm{i}}\right)
$$

where $\delta_{\mathrm{i}}$ is the effect of season or year as a moderator variable, and the other terms are as described earlier. Years 2005 to 2014 were transformed to integers ( 0 to 9 ) prior to fitting the model, then estimate statements in MIXED were used to obtain regression intercepts and slopes for the relationships between year and log severity (and $\log$ yield) for each treatment and the nontreated check. Differences in intercepts and slopes (on the log scale) between each fungicide treatment and the nontreated check were then estimated to obtain parameters for relationships between log response ratios $(\bar{L})$ and year for severity and yield. Using these parameters, predicted log response ratios $\bar{L}_{S e v}$ (and $\bar{L}_{Y l d}$ ) and the upper and lower limits of their 95\% CI were estimated for each fungicide, then back-transformed to obtain predicted percent control $\left(\bar{C}_{S e v}\right)$, yield response $\left(\bar{Y}_{Y l d}\right)$, and $\mathrm{CI}$, as explained previously.

Relative annual rate of temporal decline. The relative annual rate of reduction in percentage point per year (p.p. year ${ }^{-1}$ ) in control accuracy (and yield response) was obtained by dividing the difference in $\bar{C}_{S e v}$ (and $\bar{Y}_{Y l d}$ ) (estimated by the meta-regression model between the first and last year a given fungicide was tested) by the number of years it was tested. For example, the $\bar{C}_{S e v}$ (and $\bar{Y}_{Y l d}$ ) for CYPR in the season 2013-14 minus the estimate for the season 2005-06 (first season tested) was divided by the number of years between the first and last season of tested. For CYPR, this was 9 years.

\section{Results}

Disease severity index and soybean yield. There was considerable variation in SBR severity index and yield among treatments and trials. Median values had a range of $23 \%$ between the low and high severity and yield differed by $21 \%$ (Table 1 ). SBR severity index was generally greater (a range of $8.9 \%$ ) in treatments with single a.i. than in those with a premix of a.i. (a range of $6 \%$ ). The opposite effect was observed for yield, with premix fungicides leading to greater median yield than fungicides with a single a.i. In the nontreated check, median severity was $>35$ and $77 \%$ in more than three-quarters and one-quarter of the studies, respectively. Yield in the nonsprayed check plot was $>2,500 \mathrm{~kg} \mathrm{ha}^{-1}$ in less than onequarter of the studies (Table 1).

For most fungicides, except TRIF+PROT, a peak in mean SBR severity was apparent after the 2010 season, followed by a decrease in 2013, the year in which mean severity in the check was the lowest among the last four seasons of the study (Fig. 1). Mean yield was also variable among years as well as among fungicide treatments and the nontreated control in a given year. A pronounced reduction in mean yield for the fungicide treatments was also apparent after 2010 (Fig. 2)

Overall efficacy and yield response. Results from the network meta-analysis showed that all fungicides significantly reduced SBR severity compared with the nontreated control $\left(\bar{L}_{S e v}<0 ; P\right.$ value $<$ 0.001) (Table 2$)$. The estimated mean control efficacy $\left(\bar{C}_{S e v}\right)$, obtained after back-transforming $\bar{L}_{S e v}$, covered a range of $28 \%$ among the fungicides. Estimates of $\bar{C}_{S e v}$ were lower $(<65 \%)$ for DMI or QoI when applied alone (AZOX, CYPR, and TEBU) than for DMI + QoI premixes ( $>75 \%$ ) (Table 2). Based on $\bar{C}_{S e v}$, TRIF+PROT was the most effective premix (84\%), followed closely by PICO+CYPR $(80 \%)$ and AZOX+CYPR (79\%). Among the single-a.i. fungicides, CYPR was the least effective, with a mean control efficacy of $56 \%$, followed by TEBU and AZOX, with $\bar{C}_{S e v}$ values of 58 and $62 \%$, respectively (Table 2).

All fungicides significantly increased yield relative to the nontreated check $\left(\bar{L}_{Y l d}>0 ; P<0.001\right)$ (Table 3$)$. Single-a.i. fungicides again performed the poorest in terms of yield response, with less than a $30 \%$ overall yield response relative to the nontreated control, based on $\bar{Y}_{Y l d}$ values estimated through back-transformation of $\bar{L}_{Y l d}$. When premix fungicides were used, $\bar{Y}_{Y l d}$ covered a range of $18 \%$. The greatest $\bar{Y}_{Y l d}$ among the premix fungicides was estimated for TRIF+PROT (65\%), which was approximately $14 \%$ greater than the estimated $\bar{Y}_{Y l d}$

Table 2. Estimates of the overall mean log response ratio (effect-size), associated statistics, and calculated percent control of soybean rust (SBR) severity relative

\begin{tabular}{|c|c|c|c|c|c|c|c|c|}
\hline \multirow[b]{2}{*}{ Fungicide ${ }^{c}$} & \multicolumn{5}{|c|}{ Effect size $^{\mathrm{a}}$} & \multicolumn{3}{|c|}{ Percent control $^{b}$} \\
\hline & $\bar{L}_{S e v}$ & $\mathbf{S E}(\bar{L})$ & $C I_{\text {Lower }}$ & $C I_{\text {Upper }}$ & $P$ value & $\overline{\boldsymbol{C}}_{S e v}$ & $Y_{\text {Lower }}$ & $Y_{\text {Upper }}$ \\
\hline$\overline{A Z O X}$ & -0.964 & 0.053 & -1.067 & -0.861 & $<0.001$ & 61.8 & 57.7 & 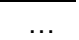 \\
\hline CYPR & -0.816 & 0.041 & -0.897 & -0.735 & $<0.001$ & 55.8 & 52.1 & 59.2 \\
\hline TEBU & -0.864 & 0.039 & -0.941 & -0.788 & $<0.001$ & 57.8 & 54.5 & 60.9 \\
\hline $\mathrm{AZOX}+\mathrm{CYPR}$ & -1.563 & 0.060 & -1.680 & -1.446 & $<0.001$ & 79.0 & 76.5 & 81.4 \\
\hline $\mathrm{PICO}+\mathrm{CYPR}$ & -1.621 & 0.063 & -1.744 & -1.498 & $<0.001$ & 80.2 & 77.6 & 82.5 \\
\hline PYRA+EPOX & -1.458 & 0.063 & -1.581 & -1.336 & $<0.001$ & 76.7 & 73.7 & 79.4 \\
\hline TRIF+PROT & -1.810 & 0.067 & -1.941 & -1.680 & $<0.001$ & 83.6 & 81.4 & 85.6 \\
\hline
\end{tabular}
to untreated check provided by seven fungicides evaluated in 250 uniform field trials conducted from the 2004-05 to 2013-14 seasons in Brazil

${ }^{a}$ Mean log response ratio $\left(\bar{L}_{S e v}\right)$ for the effect of each fungicide on SBR severity relative to the untreated check, standard error of $\bar{L}_{S e v}[\operatorname{SE}(\bar{L})]$, lower $\left(C I_{L o w e r}\right)$ and upper $\left(C I_{U p p e r}\right)$ limits of the $95 \%$ confidence interval around $\bar{L}_{S e v}$, and probability value ( $P$ value).

${ }^{b}$ Mean percent control $\left(\bar{C}_{S e v}\right)$ and lower $\left(Y_{\text {Lower }}\right)$ and upper $\left(Y_{U p p e r}\right)$ limits of the $95 \%$ confidence interval around $\bar{C}_{S e v}$ estimated by back-transforming $\bar{L}_{S e v}$ and the confidence limits around $\bar{L}_{S e v}$ as $\bar{C}_{S e v}=\left[1-\exp \left(\bar{L}_{S e v}\right)\right] \times 100$.

${ }^{c} \mathrm{AZOX}=$ azoxystrobin, $\mathrm{CYPR}=$ cyproconazole, $\mathrm{TEBU}=$ tebuconazole, $\mathrm{PICO}=$ picoxystrobin, $\mathrm{PYRA}=$ pyraclostrobin, $\mathrm{EPOX}=$ epoxiconazole, $\mathrm{TRIF}=$ trifloxystrobin, and PROT $=$ prothioconazole 
for PICO+CYPR, the second greatest. The lowest $\bar{Y}_{Y l d}$ value was estimated for CYPR, followed by TEBU and AZOX (Table 3).

Effect of year on control efficacy and yield response. The estimated intercepts for relationships between predicted $\bar{L}_{S e v}$ (and corresponding control efficacy, $\bar{C}_{S e v}$ ) and year, adjusted for the first year in which a fungicide was tested, varied among the fungicides (Table 4). Overall mean $\bar{C}_{S e v}$ (from back-transforming $\bar{L}_{S e v}$ ) ranged from 62 to $88 \%\left(\bar{L}_{S e v}=-0.98\right.$ to -2.15$)$ (Table 4$)$ in the first year a fungicide was tested. Inspection of the intercepts (Table 4) suggests that the best initial performance was observed for premix fungicides, all of which provided greater levels of control in the first year of testing than single-a.i. fungicides. For all premix fungicides, estimated mean control efficacy in the first year was $>80 \%$ (Fig. 3).

Table 3. Estimates of the overall mean log response ratio (effect-size), associated statistics, and calculated yield response (relative to untreated check) to the application of seven fungicides evaluated in 250 uniform field trials conducted from the 2004-05 to 2013-14 seasons in Brazil

\begin{tabular}{|c|c|c|c|c|c|c|c|c|}
\hline \multirow[b]{2}{*}{ Fungicide $^{c}$} & \multicolumn{5}{|c|}{ Effect size $^{\mathbf{a}}$} & \multicolumn{3}{|c|}{ Yield response $^{b}$} \\
\hline & $\bar{L}_{Y l d}$ & $\mathbf{S E}(\bar{L})$ & $C I_{\text {Lower }}$ & $C I_{\text {Upper }}$ & $P$ value & $\overline{\boldsymbol{Y}}_{Y l d}$ & $Y_{\text {Lower }}$ & $Y_{U p p e r}$ \\
\hline AZOX & 0.260 & 0.017 & 0.225 & 0.294 & $<0.001$ & 29.6 & 25.2 & \\
\hline CYPR & 0.245 & 0.014 & 0.217 & 0.272 & $<0.001$ & 27.7 & 24.2 & 31.3 \\
\hline TEBU & 0.260 & 0.013 & 0.234 & 0.286 & $<0.001$ & 29.6 & 26.3 & 33.1 \\
\hline $\begin{array}{r}\text { AZOX+ } \\
\text { CYPR }\end{array}$ & 0.401 & 0.020 & 0.362 & 0.440 & $<0.001$ & 49.2 & 43.6 & 55.2 \\
\hline $\begin{array}{c}\text { PICO+ } \\
\text { CYPR }\end{array}$ & 0.413 & 0.021 & 0.372 & 0.454 & $<0.001$ & 51.1 & 45.1 & 57.4 \\
\hline $\begin{array}{r}\text { PYRA+ } \\
\text { EPOX }\end{array}$ & 0.387 & 0.020 & 0.348 & 0.426 & $<0.001$ & 47.2 & 41.6 & 53.0 \\
\hline $\begin{array}{l}\text { TRIF+ } \\
\text { PROT }\end{array}$ & 0.500 & 0.024 & 0.452 & 0.547 & $<0.001$ & 64.8 & 57.2 & 72.8 \\
\hline
\end{tabular}

${ }^{a}$ Mean $\log$ response ratio $\left(\bar{L}_{Y l d}\right)$ for the effect of each fungicide for soybean rust management on yield relative to the untreated check, standard error of $\bar{L}_{Y l d}[\operatorname{SE}(\bar{L})]$, lower $\left(C I_{\text {Lower }}\right)$ and upper $\left(C I_{U_{p p e r}}\right)$ limits of the $95 \%$ confidence interval around $\bar{L}_{Y l d}$, and probability value ( $P$ value).

${ }^{\mathrm{b}}$ Mean percentage of yield response $\left(\bar{Y}_{Y l d}\right)$ and lower $\left(Y_{\text {Lower }}\right)$ and upper $\left(Y_{\text {Upper }}\right)$ limits of the $95 \%$ confidence interval around $\bar{Y}_{\text {Yld }}$ estimated by back-transforming $\bar{L}_{Y l d}$ and the confidence limits around $\bar{L}_{Y l d}$ as $\bar{Y}_{Y l d}=$ $\left[\exp \left(\bar{L}_{Y l d}\right)-1\right] \times 100$.

${ }^{c} \mathrm{AZOX}=$ azoxystrobin, $\mathrm{CYPR}=$ cyproconazole, $\mathrm{TEBU}=$ tebuconazole, $\mathrm{PICO}=$ picoxystrobin, $\mathrm{PYRA}=$ pyraclostrobin, $\mathrm{EPOX}=$ epoxiconazole, $\mathrm{TRIF}=$ trifloxystrobin, and $\mathrm{PROT}=$ prothioconazole.
The rates of increase in log response ratio (and corresponding reduction in $\bar{C}_{S e v}$ ) per unit time for disease severity (reflecting a decline in efficacy) also varied among fungicides, ranging from 0.028 to 0.147 and being significantly different from zero for all but one fungicide $(P<0.001)$ (Table 4$)$. TRIF+PROT was the only fungicide for which there was not a significant decline in control efficacy over time. The greatest and the lowest rate of decline in efficacy (based on regression slope) was estimated for TEBU and TRIF+PROP, respectively (Table 4; Fig. 3).

In the most recent season evaluated in this study (2013-14), the estimated control efficacy was greater than $60 \%$ for three fungicides: AZOX+CYPR, PICO+CYPR, and TRIF+PROT. TEBU showed the greatest reduction in percent control between the first and last season (78\% in 2004-05 compared with $18 \%$ in 2013-14), and TRIF+ PROT showed a relatively stable efficacy over the seasons (from $80 \%$ in $2008-09$ to $77 \%$ in $2013-14$ ) (Fig. 3).

Similarly, regression parameters for the relationships between log response ratio for yield and year also varied among fungicide treatments (Table 5). Estimated intercepts (representing yield response in year one) on the log response ratio scale $\left(\bar{L}_{Y l d}\right)$ were significantly greater than zero $(P<0.001)$, indicating that all fungicides increased yield compared with the nontreated check in the first year of testing in this study (Table 5). Correspondingly, estimated percent yield response $\left(\bar{Y}_{Y l d}\right)$ in year one also varied among treatments, ranging from 39 to $70 \%$ (Fig. 4). AZOX+CYPR performed the best among premix fungicides $\left(\bar{Y}_{Y l d}=70 \%\right)$, and TEBU among single-a.i. fungicides (54\% of $\bar{Y}_{Y l d}$ ). CYPR and AZOX had the lowest initial $\bar{Y}_{Y l d}$ values, 39 and $41 \%$, respectively, whereas the $\bar{Y}_{Y l d}$ values for all other fungicides were greater than $55 \%$ in year one (Fig. 4).

Slopes for the relationships between $\bar{L}_{Y l d}$ and yield were significantly different from zero $(P<0.001)$ for all but one fungicide (TRIF+PROT), indicating that this was the only fungicide for which there was not a significant change in yield response over the years of this study $(P=0.185)$ (Table 5). In 2013-14, for all but two fungicides (PICO+CYPR and TRIF+PROT), estimated yield response $\left(\bar{Y}_{Y l d}\right.$, ) was reduced by more than $50 \%$ compared with the first year (Fig. 4). TEBU showed the greatest decrease in $\bar{Y}_{Y l d}$, being more than six times lower in 2013-14 (8\%) than in 2004-05 (54\%). The estimated yield response in 2013-14 was reduced to less than $35 \%$ for all fungicides, except TRIF+PROT (46\%) (Fig. 4).

Relative annual rate of temporal decline. The relative annual rate of temporal decline in $\bar{C}_{S e v}$ and $\bar{Y}_{Y l d}$ in terms of p.p. year ${ }^{-1}$ is presented in Figure 5. For $\bar{C}_{S e v}$, TEBU showed the greatest rate of

Table 4. Regression parameters (intercept and slope) for the temporal change in log response ratio for soybean rust (SBR) severity $\left(\bar{L}_{S e v}\right)$ for each fungicide treatment relative to the untreated check from network meta-analysis with year as a continuous moderator variable

\begin{tabular}{|c|c|c|c|c|c|c|c|}
\hline \multirow[b]{2}{*}{ Fungicide $^{b}$} & \multirow[b]{2}{*}{ First seasonc } & \multicolumn{6}{|c|}{ Effect size $^{\mathbf{a}}$} \\
\hline & & Parameter & $\bar{L}_{S e v}$ & $\mathbf{S E}(\bar{L})$ & $C I_{\text {Lower }}$ & $C I_{\text {Upper }}$ & $P$ value \\
\hline \multirow[t]{2}{*}{ AZOX } & 2006-07 & Intercept & -1.219 & 0.087 & -1.389 & -1.048 & $<0.001$ \\
\hline & $\ldots$ & Slope & 0.101 & 0.019 & 0.064 & 0.138 & $<0.001$ \\
\hline \multirow[t]{2}{*}{ CYPR } & 2005-06 & Intercept & -0.980 & 0.074 & -1.126 & -0.834 & $<0.001$ \\
\hline & $\ldots$ & Slope & 0.061 & 0.015 & 0.031 & 0.090 & $<0.001$ \\
\hline \multirow[t]{2}{*}{ TEBU } & 2004-05 & Intercept & -1.518 & 0.065 & -1.646 & -1.390 & $<0.001$ \\
\hline & & Slope & 0.147 & 0.012 & 0.122 & 0.171 & $<0.001$ \\
\hline \multirow[t]{2}{*}{$\mathrm{AZOX}+\mathrm{CYPR}$} & 2004-05 & Intercept & -2.151 & 0.121 & -2.387 & -1.914 & $<0.001$ \\
\hline & $\ldots$ & Slope & 0.132 & 0.022 & 0.089 & 0.175 & $<0.001$ \\
\hline \multirow[t]{2}{*}{ PICO+CYPR } & 2007-08 & Intercept & -1.723 & 0.089 & -1.899 & -1.548 & $<0.001$ \\
\hline & $\ldots$ & Slope & 0.097 & 0.026 & 0.046 & 0.149 & $<0.001$ \\
\hline \multirow[t]{2}{*}{ PYRA+EPOX } & $2006-07$ & Intercept & -1.817 & 0.097 & -2.006 & -1.628 & $<0.001$ \\
\hline & $\ldots$ & Slope & 0.136 & 0.024 & 0.089 & 0.183 & $<0.001$ \\
\hline \multirow[t]{2}{*}{ TRIF+PROT } & 2008-09 & Intercept & -1.620 & 0.091 & -1.798 & -1.441 & $<0.001$ \\
\hline & $\ldots$ & Slope & 0.028 & 0.031 & -0.032 & 0.088 & 0.364 \\
\hline
\end{tabular}


reduction (7.7 p.p. year ${ }^{-1}$ ), followed by AZOX (5.4 p.p. year $\left.{ }^{-1}\right)$. For the other fungicides for which there was a significant temporal decline in efficacy (based on the slopes presented in Table 4), the rates ranged from 2.5 p.p. year ${ }^{-1}$ (PICO+CYPR) to 4.2 p.p. year ${ }^{-1}$ (CYPR)
(Fig. 5). For $\bar{Y}_{Y l d}$, the corresponding rates were 8.4 p.p. year ${ }^{-1}$ for TEBU, followed closely by AZOX (8.3 p.p. year ${ }^{-1}$ ). For all the other fungicides for which slopes for relationships between $\bar{L}_{Y l d}$ and year were significantly different from zero (indicative of a temporal
Azoxystrobin

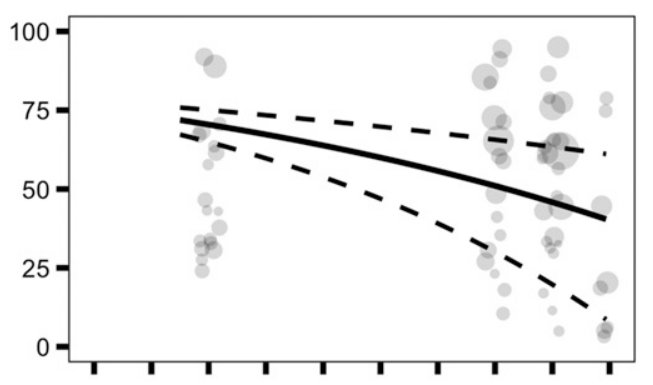

Tebuconazole

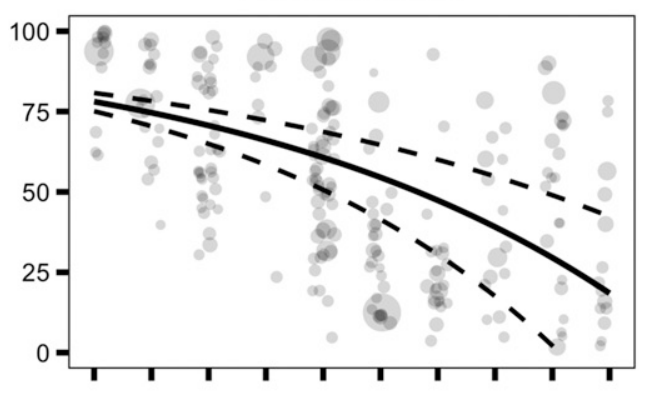

Picoxystrobin + Cyproconazole

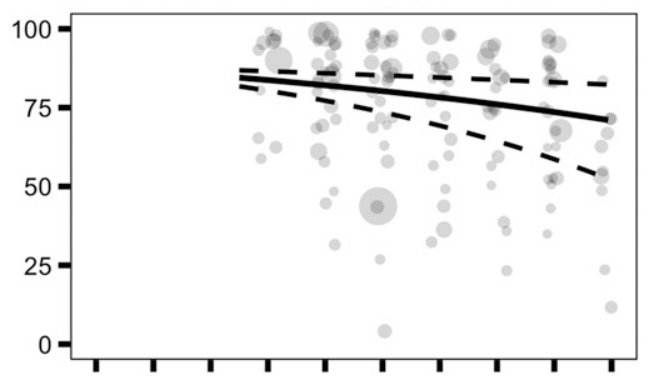

Trifloxystrobin + Prothioconazole

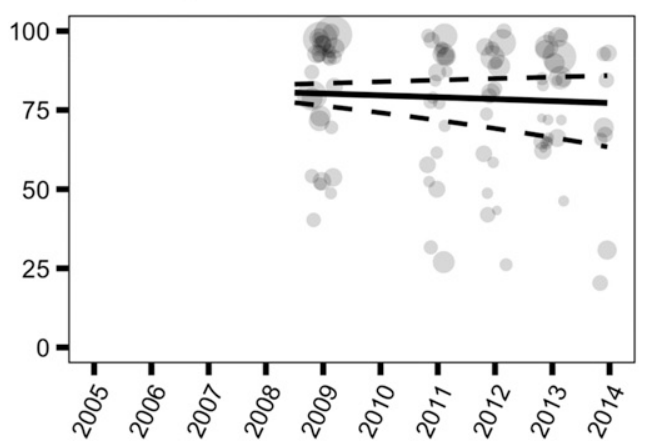

\section{Cyproconazole}

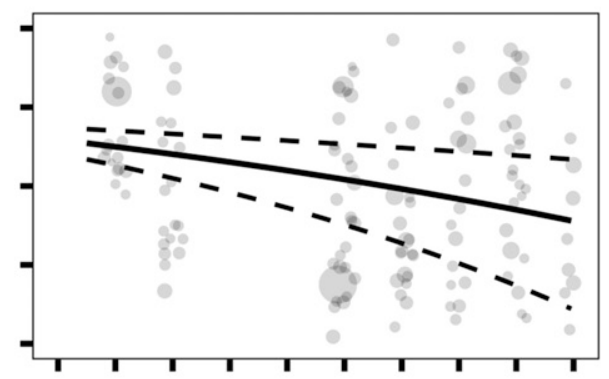

Azoxystrobin + Cyproconazole

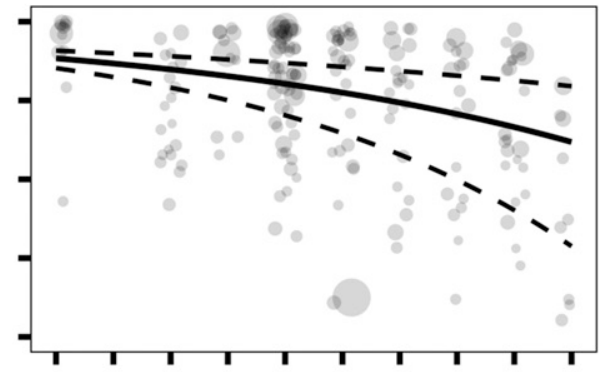

\section{Pyraclostrobin + Epoxiconazole}

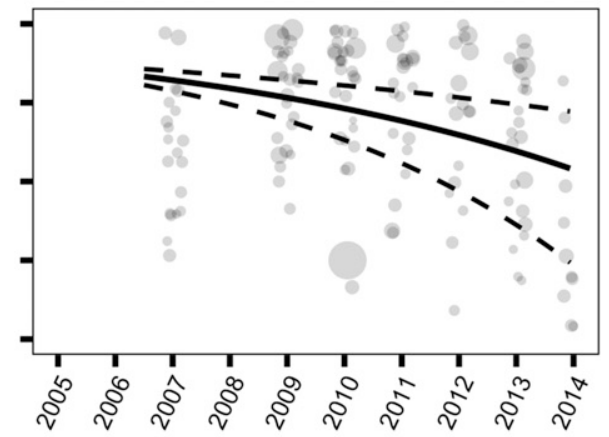

Fig. 3. Temporal change in the efficacy of different fungicide treatments against soybean rust. Solid (mean) and dashed (95\% confidence interval) lines represent estimated mean control efficacy relative to the untreated check obtained through back-transformation of predicted the log response ratio (severity in the treatment relative to severity in the check) for each year estimated by network meta-regression modeling, with year as a continuous moderator variable. Dots represent percent control from each individual trial, calculated by $100 \times\left[1-\left(S E V_{\text {Fung }} / S E V_{\text {Check }}\right)\right]$, where $S E V_{\text {Fung }}$ represents mean severity for the treatment and $S E V_{\text {Check }}$ represents mean severity for the untreated control. The size of the dot is proportional to sampling variance; the higher the sampling variance, the smaller the dots. A small random noise (variation on $x$ value) was applied in the data within a year to avoid overlapping. 
decline in yield response), the rates ranged from 5.8 p.p. year ${ }^{-1}$ (AZOX+CYPR) to 7.4 p.p. year ${ }^{-1}$ (PYRA+EPOX).

\section{Discussion}

Similar to observations made by Scherm et al. (2009), our analysis reported a superior performance of premix QoI + DMI fungicides against SBR compared with single-a.i. DMI or QoI. The performance of the mixtures was more stable over time compared with TEBU and AZOX, fungicides that contain a single a.i. A previous quantitative summary of the control efficacy and yield response of 22 fungicides tested for efficacy against SBR, including most of those evaluated in our study, reported similar superiority of the mixtures compared with single-a.i. fungicides (Scherm et al. 2009). However, the current study was limited to the first 4 years of fungicide evaluation for SBR management in Brazil (2003-04 to 2006-07), before any decline in the efficacy was apparent.

The variability in the performance of fungicides against SBR was determined to be influenced by seasonal environmental conditions; whether the first spray was applied in the absence (preventatively) or presence (curatively) of symptoms; and, largely, by the number of sprays (Scherm et al. 2009). The fact that the overall median severity in the nontreated check was as high as $60 \%$ in more than 200 trials under natural epidemics suggests that seasonal environmental conditions in this study were generally favorable for SBR (Del Ponte et al. 2006). In addition, most trials of the network were sown relatively late (November to December) to ensure greater inoculum load than commercial fields planted early, which contributes to increased disease risk. Commercial fields are sown from the end of the soybeanfree period ending at 15 September in the first regions.

A significant decline in the performance of the fungicides, which resulted in reduced levels of control efficacy and yield response over a period of time as short as 4 years, was detected for most fungicides evaluated, except for TRIF+PROT. Because seasonal environmental conditions vary randomly, the poor fungicide performances are possibly linked to reports of resistance to DMI and QoI fungicides in the Brazilian P. pachyrhizi population (Klosowski et al. 2016; Schmitz et al. 2013). PROT, included in the only mixture for which fungicide efficacy did not decline significantly, is the newest a.i. among the DMI evaluated in this study but is widely used for managing foliar diseases in soybean as well as other crops (Kuck et al. 2012). The sensitivity of $P$. pachyrhizi isolates sampled between 2008 and 2011 from all over Brazil exhibited a stronger intrinsic activity of PROT (a nontriazole but triazolinthione DMI) against the pathogen as compared with single-a.i. triazoles, including CYPR, metconazole, and TEBU (Xavier et al. 2015). Although a decline in sensitivity to PROT has been recorded for some fungal pathogens such as Mycosphaerella graminicola (Cools and Fraaije 2012), Pyrenopeziza brassicae (Carter et al. 2014) and Ascochyta rabiei (Wise et al. 2011), fairly stable performance in terms of efficacy without complete resistance are still being reported in several cases where other DMI are no longer effective (Cools et al. 2013).

The monitoring of resistance in the SBR populations using bioassay started in 2005 in Brazil but results were not made available in the literature. Surveys of pathogenic isolates collected during the 2010 growing season in Brazil showed that amino acid substitutions at positions 120 (F120L), 131 (Y131H/F), 142 (K142R), 145 (I145F), and 475 (I475T) in the CYP51 gene were associated with increased $50 \%$ effective concentration $\left(\mathrm{EC}_{50}\right)$ for the DMI fungicides epoxiconazole (EPOX), metconazole, and TEBU (Schmitz et al. 2013). In fact, a steep decline in the performance of TEBU and CYPR applied alone was observed after 2010 in the current study. Although cross-resistance has been reported for DMI (Cools and Fraaije 2012), single-point substitutions may have different effects on a.i. in this group. For instance, for M. graminicola in wheat, a strong selection for I381 V (a substitution in CYP51) was observed after application of TEBU, difenoconazole, and, to a lesser extent, metconazole; whereas, for most other -azoles, selection for I381V was either weak (e.g., EPOX and tetraconazole) or absent (e.g., flutriafol and flusilazole), and a negative selection for this substitution was observed in populations treated with prochloraz (Fraaije et al. 2007). For SBR, due to the difficulties of working with monosporic isolates, few studies of fungicide resistance are available and none of these show how substitution affects the response to different DMI.

The most commonly reported substitution in QoI-resistant pathogens is G143A, which confers complete resistance (Gisi et al. 2002); however, this mutation was reported to be lethal for some fungi, including Phakopsora pachyrhizi (Grasso et al. 2006). In addition to G143A, the F129 and the G137R substitution are associated with low to moderate levels of sensitivity reduction (Oliver 2014; Pasche et al. 2004; Sierotzki 2015). Klosowski et al. (2016) first reported the occurrence of the F129L substitution in $P$. pachyrhizi isolates collected in 2012-13, with an increase in frequency in 2013-14. As is the case with DMI, although cross-resistance is reported for QoI, the effect of substitutions may vary among a.i. contained in the group. For Alternaria solani isolates possessing the F129L substitution, a highly significant and strong association among isolates tested for cross-sensitivity was detected between AZOX and PYRA

Table 5. Regression parameters (intercept and slope) for the temporal change in log response ratio for yield $\left(\bar{L}_{Y l d}\right)$ for each fungicide treatment relative to the untreated check from network meta-analysis with year as a continuous moderator variable

\begin{tabular}{|c|c|c|c|c|c|c|c|}
\hline \multirow[b]{2}{*}{ Fungicide $^{b}$} & \multirow[b]{2}{*}{ First season ${ }^{\mathrm{c}}$} & \multicolumn{6}{|c|}{ Effect size $^{\mathbf{a}}$} \\
\hline & & Parameter & $\bar{L}_{Y l d}$ & $\mathbf{S E}(\bar{L})$ & $C I_{\text {Lower }}$ & $C I_{\text {Upper }}$ & $P$ value \\
\hline \multirow[t]{2}{*}{ AZOX } & 2006-07 & Intercept & 0.346 & 0.028 & 0.291 & 0.401 & $<0.001$ \\
\hline & $\ldots$ & Slope & -0.031 & 0.006 & -0.043 & -0.018 & $<0.001$ \\
\hline \multirow[t]{2}{*}{ CYPR } & 2005-06 & Intercept & 0.329 & 0.024 & 0.282 & 0.377 & $<0.001$ \\
\hline & & Slope & -0.024 & 0.005 & -0.034 & -0.014 & $<0.001$ \\
\hline \multirow[t]{2}{*}{ TEBU } & 2004-05 & Intercept & 0.432 & 0.023 & 0.387 & 0.477 & $<0.001$ \\
\hline & $\ldots$ & Slope & -0.039 & 0.004 & -0.048 & -0.030 & $<0.001$ \\
\hline \multirow[t]{2}{*}{$\mathrm{AZOX}+\mathrm{CYPR}$} & 2004-05 & Intercept & 0.530 & 0.038 & 0.456 & 0.605 & $<0.001$ \\
\hline & $\ldots$ & Slope & -0.030 & 0.007 & -0.045 & -0.016 & $<0.001$ \\
\hline \multirow[t]{2}{*}{ PICO+CYPR } & 2007-08 & Intercept & 0.436 & 0.026 & 0.385 & 0.486 & $<0.001$ \\
\hline & & Slope & -0.027 & 0.008 & -0.043 & -0.011 & 0.001 \\
\hline \multirow[t]{2}{*}{ PYRA+EPOX } & 2006-07 & Intercept & 0.478 & 0.028 & 0.423 & 0.532 & $<0.001$ \\
\hline & $\ldots$ & Slope & -0.036 & 0.007 & -0.050 & -0.022 & $<0.001$ \\
\hline \multirow[t]{2}{*}{ TRIF+PROT } & 2008-09 & Intercept & 0.443 & 0.028 & 0.389 & 0.498 & $<0.001$ \\
\hline & $\ldots$ & Slope & -0.013 & 0.010 & -0.032 & 0.006 & 0.185 \\
\hline
\end{tabular}

${ }^{a}$ Log response ratio $\left(\bar{L}_{Y l d}\right)$ for the effect of fungicides used for SBR management on yield relative to the untreated check, standard error of $\left.\bar{L}_{Y l d}[\mathrm{SE} \bar{L})\right]$ lower $\left(C I_{\text {Lower }}\right)$ and upper $\left(C I_{\text {Upper }}\right)$ limits of the $95 \%$ confidence interval around $\bar{L}_{Y l d}$, and probability value ( $P$ value).

${ }^{\mathrm{b}} \mathrm{AZOX}=$ azoxystrobin, $\mathrm{CYPR}=$ cyproconazole, $\mathrm{TEBU}=$ tebuconazole, $\mathrm{PICO}=$ picoxystrobin, $\mathrm{PYRA}=$ pyraclostrobin, $\mathrm{EPOX}=$ epoxiconazole, $\mathrm{TRIF}=$ trifloxystrobin, and PROT $=$ prothioconazole.

${ }^{\mathrm{c}}$ First season in which the fungicide was tested in the soybean rust Uniform Fungicide Trial. 
(Pasche et al. 2005). However, the association between AZOX and TRIF and between TRIF and PYRA was weak, although significant (Pasche et al. 2004). Pyricularia grisea isolates carrying the F129L substitution produced a 140 -fold increase in $\mathrm{EC}_{50}$ over baseline for
AZOX but only a 30 -fold increase in the $\mathrm{EC}_{50}$ for TRIF (Kim et al. 2003). The reduced level of cross-sensitivity between TRIF and AZOX based on F129L may, in part, explain why the TRIF+ PROT premix did not exhibit a significant reduction in efficacy.
Azoxystrobin

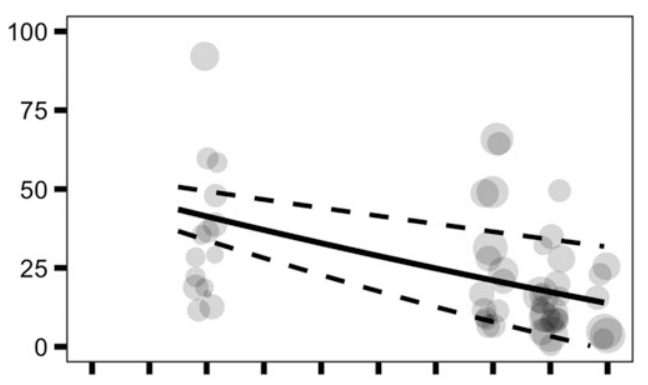

Tebuconazole

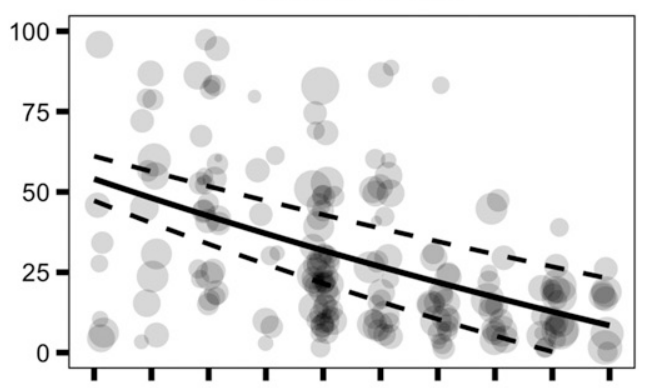

Picoxystrobin + Cyproconazole

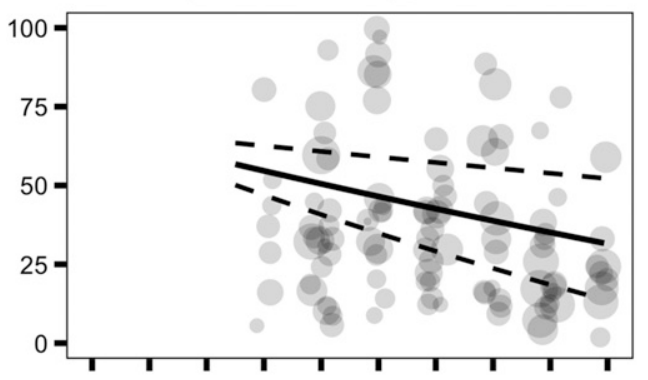

Trifloxystrobin + Prothioconazole

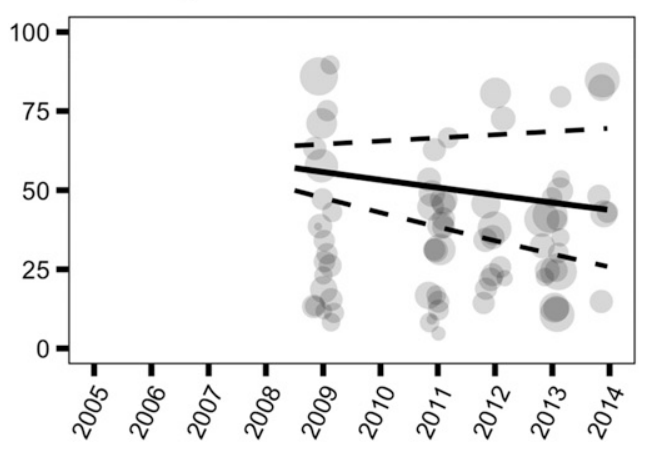

Cyproconazole

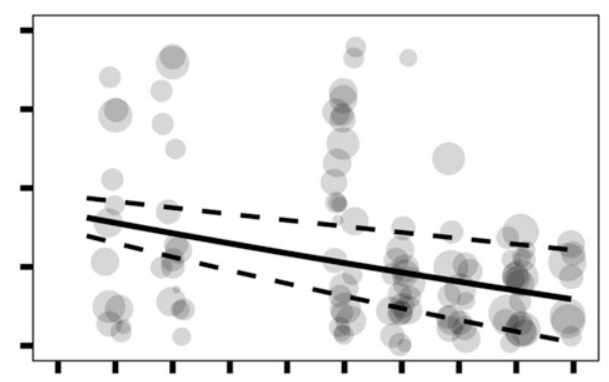

Azoxystrobin + Cyproconazole

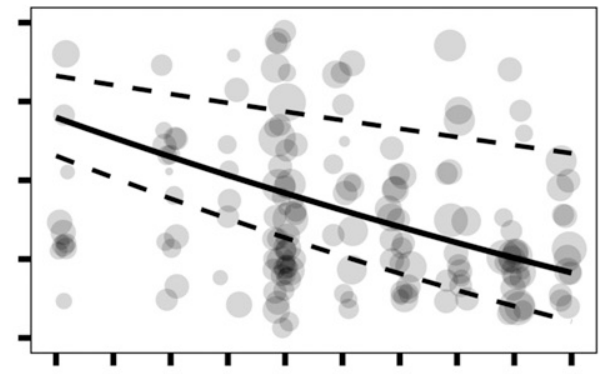

\section{Pyraclostrobin + Epoxiconazole}

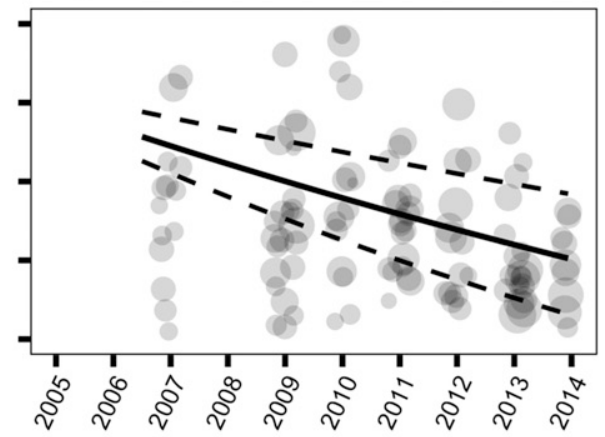

Fig. 4. Temporal change in percent soybean yield response for different fungicide treatments applied for soybean rust management. Solid (mean) and dashed (95\% confidence interval) lines represent estimated mean yield response relative to the untreated check obtained through back-transformation of predicted log response ratios (yield in the treatment relative to yield in the check) estimated by network meta-regression modeling with year as a continuous moderator variable. Dots represent percent yield response from each individual trial, calculated by $100 \times\left[\left(Y L D_{\text {Fung }} / Y L D_{\text {Check }}\right)-1\right]$, where $Y L D_{\text {Fung }}$ represents mean yield for the treatment and $Y L D_{C h e c k}$ represents mean yield for the untreated control, and the size of the dot is proportional to sampling variance; the higher the sampling variance, the smaller the dots. A small random noise (variation on $x$ value) was applied in the data within a year to avoid overlapping. 
In recent UFT (2015-16 growing season), new premixes containing SDHI were evaluated and results of the first 2 years of testing showed similar or superior performance compared with TRIF+ PROT, and DMI + QoI premixes amended with a multisite fungicide (mancozeb) (Godoy et al. 2016b). The continuing use of the same (or related) fungicide a.i. may be the driving force for the development of resistance to the fungicide that ultimately results in control failures. In the current study, the decline was not limited to single-a.i. fungicides but also applied to the premixes after repeated use for at least four consecutive years. The reasons for the decline may be related to the emergence of a Phakopsora pachyrhizi population containing point substitutions conferring a loss of sensitivity to both DMI and QoI fungicides. These results reinforce the need for continued efforts by the cooperative trials that should be conducted annually to monitor the performance of the recommended fungicides, beyond testing of new formulations, given the emergence and rapid spread of resistant SBR populations. An ongoing strategy to reduce the dependence on fungicides includes a regulation that limits the sowing period in four states, in addition to the 60 to 90 days of soybean-free period during the winter (Godoy et al. 2016a), and the suspension of fungicides that provide unsatisfactory control of SBR based on the results of the UFT conducted. The results of our meta-analytic study are important as a basis for such regulatory measures as well as to provide, using a metaanalytical approach, quantitative risk information with regards to a time frame for the development of resistance to specific fungicides over large areas. The information contained herein may be useful for other pathosystems or regions experiencing similar conditions and management based on sequential fungicide sprays.

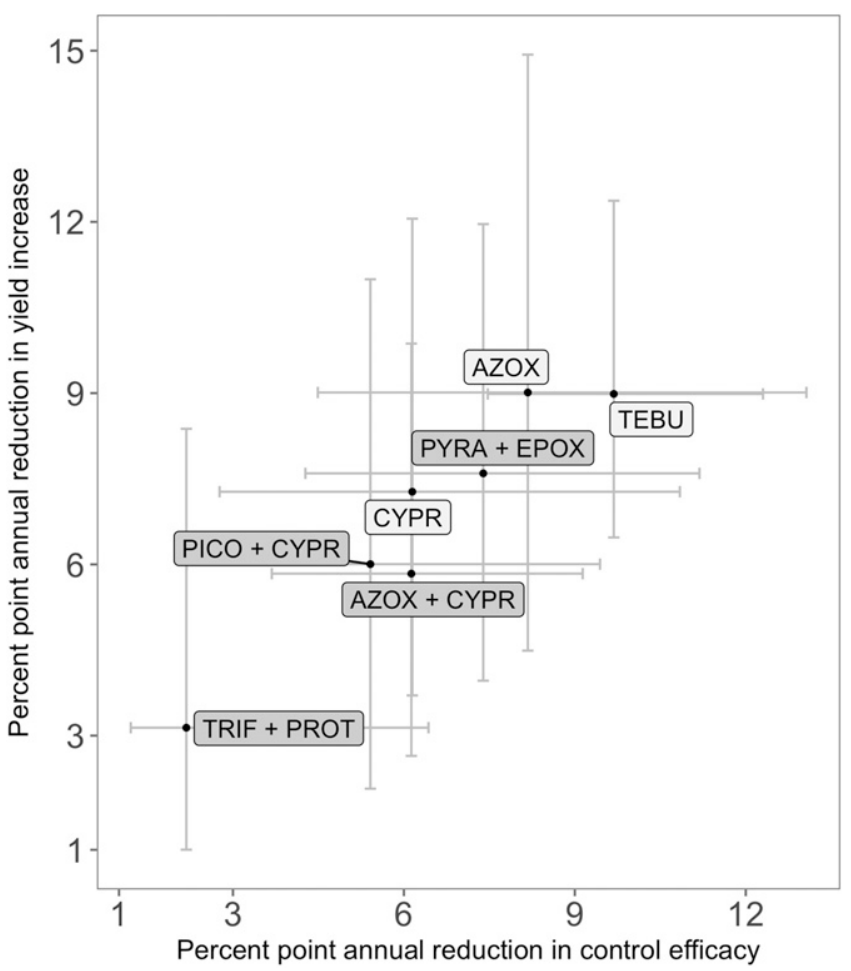

Fig. 5. Scatter plot of percentage point reduction in control efficacy versus percentage point reduction in yield response for different fungicides evaluated for their effects on soybean rust and yield in field trials conducted in Brazil between 2005 and 2014. Solid circles are relative annual rates (black circles represent single-active-ingredient fungicide and gray circles represent premixes) estimated as differences in mean control efficacy and mean yield response between the first and last year a given fungicide was tested divided by the total number of years of testing. Bars show the upper and lower limits of $95 \%$ confidence intervals around point estimates (rates) for both responses. AZOX = azoxystrobin, CYPR = cyproconazole, TEBU = tebuconazole, PICO = picoxystrobin, PYRA = pyraclostrobin, EPOX = epoxiconazole, $\mathrm{TRIF}=$ trifloxystrobin, and $\mathrm{PROT}=$ prothioconazole

\section{Acknowledgments}

We thank the National Council for Scientific and Technological Development for providing a research fellowship to E. M. Del Ponte.

\section{Literature Cited}

Carter, H. E., Fraaije, B. A., West, J. S., Kelly, S. L., Mehl, A., Shaw, M. W., and Cools, H. J. 2014. Alterations in the predicted regulatory and coding regions of the sterol 14 $\alpha$-demethylase gene (CYP51) confer decreased azole sensitivity in the oilseed rape pathogen Pyrenopeziza brassicae. Mol. Plant Pathol. 15:513-522.

Cools, H. J., and Fraaije, B. A. 2012. Update on mechanisms of azole resistance in Mycosphaerella graminicola and implications for future control. Pest Manage. Sci. 69:150-155.

Cools, H. J., Hawkins, N. J., and Fraaije, B. A. 2013. Constraints on the evolution of azole resistance in plant pathogenic fungi. Plant Pathol. 62:36-42.

Dalla Lana, F., Ziegelmann, P. K., Maia, A. D. H. N., Godoy, C. V., and Del Ponte, E. M. 2015. Meta-analysis of the relationship between crop yield and soybean rust severity. Phytopathology 105:307-315.

Del Ponte, E. M., and Esker, P. D. 2008. Meteorological factors and Asian soybean rust epidemics: A systems approach and implications for risk assessment. Sci. Agric. 65:88-97.

Del Ponte, E. M., Godoy, C. V., Canteri, M. G., Reis, E. M., and Yang, X. B. 2006. Models and applications for risk assessment and prediction of Asian soybean rust epidemics. Fitopatol. Bras. 31:533-544

Fehr, W. R., Caviness, C. E., Burmood, D. T., and Pennington, J. S. 1971. Stage of development descriptions for soybeans, Glycine max (L.) Merrill1. Crop Sci 11:929-931.

Fraaije, B. A., Cools, H. J., Kim, S. H., Motteram, J., Clark, W. S., and Lucas, J. A. 2007. A novel substitution I381V in the sterol $14 \alpha$-demethylase (CYP51) of Mycosphaerella graminicola is differentially selected by azole fungicides. Mol. Plant Pathol. 8:245-254.

Gisi, U., Sierotzki, H., Cook, A., and McCaffery, A. 2002. Mechanisms influencing the evolution of resistance to Qo inhibitor fungicides. Pest Manage. Sci. 58:859-867.

Godoy, C. V., Koga, L. J., and Canteri, M. G. 2006. Diagrammatic scale for assessment of soybean rust severity. Fitopatol. Bras. 31:63-68.

Godoy, C. V., Seixas, C. D. S., Soares, R. M., Marcelino-Guimarães, F. C., Meyer, M. C., and Costamilan, L. M. 2016a. Asian soybean rust in Brazil: Past, present, and future. Pesqui. Agropecu. Bras. 51:407-421.

Godoy, C. V., Utiamada, C. M., Meyer, M. C., Campos, D. H., Forcelini, C. A., Pimenta, C. B., Borges, E. P., Andrade, E. R., Siqueri, F. V., Juliatti, F. C., Favero, F., Feksa, H. R., Grigolli, J. F. J., Nunes, J., Jr., Carneiro, L. C., Silva, L. H. C. P., Sato, L. N., Canteri, M. G., Volf, M. R., Debortoli, M. P., Goussain, M., Martins, M. C., Balardin, R. S., Furlan, S. H., Madalosso, T., Carlin, V. J., and Venancio, W. S. 2016b. Eficiência de fungicidas para o controle da ferrugem-asiática da soja, Phakopsora pachyrhizi, na safra 2015/16: Resultados sumarizados dos ensaios cooperativos. Circ. Tec. 119: $1-6$.

Grasso, V., Palermo, S., Sierotzki, H., Garibaldi, A., and Gisi, U. 2006. Cytochrome $b$ gene structure and consequences for resistance to Qo inhibitor fungicides in plant pathogens. Pest Manage. Sci. 62:465-472.

Hartman, G. L., Sinclair, J. B., and Rupe, J. C., eds. 1999. Compendium of Soybean Diseases, 4th ed. American Phytopathological Society, St. Paul, MN.

Hulvey, J., Popko, J. T., Sang, H., Berg, A., and Jung, G. 2012. Overexpression of ShCYP51B and ShatrD in Sclerotinia homoeocarpa isolates exhibiting practical field resistance to a demethylation inhibitor fungicide. Appl. Environ. Microbiol. 78:6674-6682.

Ivancovich, A. 2005. Soybean rust in Argentina. Plant Dis. 89:667-668.

Kim, Y. S., Dixon, E. W., Vincelli, P., and Farman, M. L. 2003. Field resistance to strobilurin (QoI) fungicides in Pyricularia grisea caused by mutations in the mitochondrial cytochrome b gene. Phytopathology 93:891-900.

Klosowski, A. C., May De Mio, L. L., Miessner, S., Rodrigues, R., and Stammler, G. 2016. Detection of the F129L mutation in the cytochrome $b$ gene in Phakopsora pachyrhizi. Pest Manage. Sci. 72:1211-1215.

Kuck, K. H., Stenzel, K., and Vors, J. P. 2012. Sterol biosynthesis inhibitors. Pages 761-805 in: Modern Crop Protection Compounds, 2nd ed. W. Kramer, U. Schirmer, P. Jeschke, and M. Witschel, eds. Wiley-VCH, Weinheim, Germany.

Kumudini, S., Godoy, C. V., Board, J. E., Omielan, J., and Tollenaar, M. 2008. Mechanisms involved in soybean rust-induced yield reduction. Crop Sci. 48: 2334-2342.

Li, X., Esker, P. D., Pan, Z., Dias, A. P., Xue, L., and Yang, X. B. 2010. The uniqueness of the soybean rust pathosystem: An improved understanding of the risk in different regions of the world. Plant Dis. 94:796-806.

Littell, R. C., Milliken, G. A., Stroup, W. W., Wolfinger, R. D., and Oliver, S 2006. SAS for Mixed Models, 2nd ed. SAS institute, Cary, NC.

Ma, B., and Tredway, L. P. 2013. Induced overexpression of cytochrome P450 sterol $14 \alpha$-demethylase gene (CYP51) correlates with sensitivity to demethylation inhibitors (DMIs) in Sclerotinia homoeocarpa. Pest Manage. Sci. 69:1369-1378.

Madden, L. V., and Paul, P. A. 2011. Meta-analysis for evidence synthesis in plant pathology: An overview. Phytopathology 101:16-30.

Madden, L. V., Piepho, H. P., and Paul, P. A. 2016. Statistical models and methods for network meta-analysis. Phytopathology 106:792-806. 
Miles, M. R., Frederick, R. D., and Hartman, G. L. 2006. Evaluation of soybean germplasm for resistance to Phakopsora pachyrhizi. Online publication. Plant Health Prog. doi.org/10.1094/PHP-2006-0104-01-RS

Oliver, R. P. 2014. A reassessment of the risk of rust fungi developing resistance to fungicides. Pest Manage. Sci. 70:1641-1645.

Pasche, J. S., Piche, L. M., and Gudmestad, N. C. 2005. Effect of the F129L mutation in Alternaria solani on fungicides affecting mitochondrial respiration. Plant Dis. 89:269-278.

Pasche, J. S., Wharam, C. M., and Gudmestad, N. C. 2004. Shift in sensitivity of Alternaria solani in response to QoI fungicides. Plant Dis. 88:181-187.

Paul, P. A., Lipps, P. E., Hershman, D. E., McMullen, M. P., Draper, M. A., and Madden, L. V. 2008. Efficacy of triazole-based fungicides for fusarium head blight and deoxynivalenol control in wheat: A multivariate meta-analysis. Phytopathology 98:999-1011.

Paul, P. A., McMullen, M. P., Hershman, D. E., and Madden, L. V. 2010. Meta-analysis of the effects of triazole-based fungicides on wheat yield and test weight as influenced by Fusarium head blight intensity. Phytopathology 100:160-171.

Pivonia, S., and Yang, X. B. 2004. Assessment of the potential year-round establishment of soybean rust throughout the world. Plant Dis. 88:523-529.

Rossi, R. L. 2003. First report of Phakopsora pachyrhizi, the causal organism of soybean rust in the province of Misiones, Argentina. Plant Dis. 87:102.

Scherm, H., Christiano, R. S. C., Esker, P. D., Del Ponte, E. M., and Godoy, C. V. 2009. Quantitative review of fungicide efficacy trials for managing soybean rust in Brazil. Crop Prot. 28:774-782.

Schmitz, H. K., Medeiros, C. A., Craig, I. R., and Stammler, G. 2013. Sensitivity of Phakopsora pachyrhizi towards quinone-outside-inhibitors and demethylation-inhibitors, and corresponding resistance mechanisms. Pest Manage. Sci. 70:378-388

Schneider, R. W., Hollier, C. A., Whitam, H. K., Palm, M. E., McKemy, J. M. Hernández, J. R., Levy, L., and DeVries-Paterson, R. 2005. First report of soybean rust caused by Phakopsora pachyrhizi in the continental United States. Plant Dis. 89:774.

Sierotzki, H. 2015. Respiration inhibitors: Complex III. Pages 119-143 in: Fungicide Resistance in Plant Pathogens. H. Ishii and D. W. Holloman, eds Springer, Tokyo.

Stammler, G., Cordero, J., Koch, A., Semar, M., and Schlehuber, S. 2009. Role of the Y134F mutation in CYP51 and overexpression of CYP51 in the sensitivity response of Puccinia triticina to epoxiconazole. Crop Prot. 28:891-897.

Wise, K. A., Bradley, C. A., Markell, S., Pasche, J., Delgado, J. A., Goswami, R. S., and Gudmestad, N. C. 2011. Sensitivity of Ascochyta rabiei populations to prothioconazole and thiabendazole. Crop Prot. 30:1000-1005.

Xavier, S. A., Koga, L. J., Barros, D. C. M., Canteri, M. G., Lopes, I. O. N., and Godoy, C. V. 2015. Variação da sensibilidade de populações de Phakopsora pachyrhizi a fungicidas inibidores da desmetilação no Brasil. Summa Phytopathol. 41:191-196.

Yang, X. B., Tschanz, A. T., Dowler, W. M., and Wang, T. C. C. 1991. Development of yield loss models in relation to reductions of components of soybean infected with Phakopsora pachyrhizi. Phytopathology 81:1420-1426.

Yorinori, J., Paiva, W., Frederick, R. R. D., Costamilan, L., Bertagnolli, P., Hartman, G. L., Godoy, C. V., and Nunes, J., Jr. 2005. Epidemics of soybean rust (Phakopsora pachyrhizi) in Brazil and Paraguay from 2001 to 2003. Plant Dis. 89:675-677. 